\title{
Effects of Fertilizer Broadcasting on the Excessive Use of Inorganic Fertilizers and Environmental Sustainability
}

\author{
K. M. Atikur Rahman and Dunfu Zhang *
}

School of Sociology and Political Science, Shanghai University, 99, Shangda Road, Shanghai 200444, China; atik73@i.shu.edu.cn

* Correspondence: paulchang@staff.shu.edu.cn; Tel.: +86-021-6442-5369

Received: 21 January 2018; Accepted: 8 March 2018; Published: 9 March 2018

\begin{abstract}
The excessive use of inorganic fertilizers causes serious environmental degradation, resulting in lower crop yields in Bangladesh. Seventy percent of Bangladesh farmers practice traditional fertilizer broadcasting. In the 1960s, the Bangladesh state authority launched a 'Grow More Food' campaign to feed the country's increasing population. Farmers were supplied with chemical fertilizers and pesticides at a subsidized price. Farmers increased the frequency of fertilizer applications to enhance yields. These practices are still used and have caused significant environmental degradation. In this study, we examined the effects of fertilizer broadcasting on excessive use of fertilizer and environmental risks. We collected data from 211 Bangladesh infield farmers in 2016. Respondents were interviewed using a semi-structured questionnaire. Data were analyzed by applying a binary logistic regression model to test the degree of effects between the testable variables. The study found that the effect of broadcasting on the excessive use of fertilizers is strongly significant, at $1 \%$. It also found that younger farmers have a significant effect at $10 \%$ on the excessive use of fertilizers. Bangladesh policymakers can formulate policy on sustainable fertilizer management, introducing different placement methods on the basis of this finding. After that, the Directorate of Agricultural Extension (DAE) can carry out the policy at the field level.
\end{abstract}

Keywords: excessive use of fertilizers; environmental degradation; fertilizer broadcasting; rental land farming; placement method; sustainable fertilizer management

\section{Introduction}

The proportion of the world's population that is hungry has dramatically decreased due to the marked growth in food production in the last 50 years [1,2]. This has significantly decreased the proportion of malnourished people [1] even as the continuing growth of the global population, expected to plateau at approximately 9 billion people by 2050, will result in greater competition for land, water, and energy $[3,4]$. To feed the world population, the intensity of agricultural production has to be significantly increased [3,5]. Advanced agricultural technologies, such as efficient fertilization methods, are required to meet the global demand, as the inefficient and excessive use of inorganic fertilizers can cause environmental risks. For example, concurrent with the recent increase in agricultural productivity, agricultural systems are now also recognized to be a significant source of environmental damage $[3,6,7]$. The doubling of agricultural food production worldwide up to the 1990s can be partly attributed to a 6.9-fold increase in nitrogen $(\mathrm{N})$ fertilization and a 3.5-fold increase in phosphorous $(\mathrm{P})$ fertilization [8,9]. For example, in China, more than half of increased crop production was based on a rapid increase in the consumption of fertilizers $[7,10]$.

Farmers of some developing countries apply fertilizers to their cropland excessively and indiscriminately because of a lack of training in continuous innovations [11]. These countries include Bangladesh, where unsustainable fertilization is heavily practiced. On the other hand, several 
developed countries apply inorganic fertilizers efficiently as they are adopting fertilizer management technologies [11]. For instance, the normalized differential vegetative index (NDVI) has been used for decades as a predictor of vegetative biomass [11,12], and precision agriculture technology (PAT) has recently been receiving more attention from researchers [13]. In many developing countries there are many fertilizer management technologies suited to regional agricultural and socio-cultural structures, such as crop management knowledge models [13,14], $\mathrm{N}$ fertilizer models [14], leaf color charts (LCC) [15], and soil-plant analysis development (SPAD) [16], but adoption rates are very low.

Over-fertilization (excessive use of fertilizers) (i.e., the application of fertilizer nitrogen $(\mathrm{N})$ in excess of the tree or vine capacity to use it for optimum productivity) is associated with high levels of residual nitrate in the soil, which potentially contribute to groundwater and atmospheric pollution as a result of leaching, gentrification, etc. [17]. It is associated with high levels of residual nitrate and other toxins in the soil, which potentially contribute to groundwater and atmospheric pollution [17]. Over-fertilization also may adversely affect productivity and fruit or crop quality [17]. Traditional fertilizer broadcasting, in which fertilizers are cast across the surface of crop fields by hand, a method that cannot control the rate of nutrient frequency, triggers inefficient fertilization. It increases production costs by roughly $33 \%$ and greenhouse gases by $60 \%$ and also decreases yields by roughly $15-18 \%$ [18]. Two-thirds of the urea broadcast in wetland rice production is lost to the environment [18]. Traditional broadcasting methods result in losing the greater part of fertilizer due to rain, irrigation, or sublimation by sun radiation [19].

Excessive use of fertilizers has been a great challenge to Bangladesh agriculture. According to the 2005 National Fertilizer Recommendation Guide, on average, farmers overuse urea [18] and fertilizer use has been increased by $400 \%$ in the last 30 years [20-22]. Urea, triple superphosphate (TSP), and muriate of potash $(\mathrm{MoP})$ are the main inorganic fertilizers used in Bangladesh, with nitrogen (urea) alone constituting about $75 \%$ of nutrient use $[23,24]$. Crystal urea is applied predominantly via broadcasting, which consumes $20-25 \%$ more nutrients than deep placement application $[25,26]$. As of 2012, only 2.5 million farmers used deep placement; the rest practice the broadcasting [18]. Foliar spray and localized methods are also employed by a limited number of farmers [23].

Although agriculture is a minor emitter of $\mathrm{CO}_{2}$, it is a major emitter of $\mathrm{N}_{2} \mathrm{O}$ and $\mathrm{CH}_{4}$ [27]. Disparate fertilizer broadcasting will result in nonuniform growth, emissions, fertilizer waste, and a decrease in the usage coefficient of the plant $[28,29]$. Nitrogen-containing fertilizers are the leading sources of environmental degradation when they are applied in excessive volumes [30]. Nitrogen fertilizers also contribute to global greenhouse gas emissions (GHG), as they are one of the major anthropogenic sources of nitrous oxide $\left(\mathrm{N}_{2} \mathrm{O}\right)$. Further, fertilizers also impact fishery and forestry [31,32].

Bangladesh uses about $198 \mathrm{~kg}$ per ha/year of inorganic fertilizers [33,34]. High level of sodium and potassium-containing fertilizers negatively impact soil $\mathrm{pH}$ and structure [35]. All types of fertilizers (nitrogen, sodium, and potassium) are used for broadcasting, as other methods (band, placement, fertigation) are efficient but are costly and labor-intensive and thus are not affordable to farmers. Nitrogen-containing fertilizers are applied more than those containing sodium and potassium in Bangladesh. Continuous use of nitrogen fertilizers causes a decrease in soil $\mathrm{pH}$ declining the efficiency of field crops [36].

In the early 1950s, Bangladesh farmers applied only organic manures to their croplands [34]. In that period, agricultural productivity was less than it is currently, but sustainability in the agricultural environment was well balanced. In 1965, the government launched the 'Grow More Food' campaign, providing chemical fertilizers and pesticides at subsidized prices [37,38]. Farmers observed that chemical fertilizers and pesticides increased yields like magic, and therefore increased fertilizer application frequency in the 1980s. These practices are still continued [39]. A large number of Bangladesh farmers are informally educated, untrained, small landowners, unconscious of their health and environment [38]. They cultivate lands rented from others at a high price in methods that are practical for short tenures, aspiring to gain higher yields through the excessive use of fertilizers. 
Fertilizer consumption per hectare in Bangladesh is considerably lower than in many developed countries, but higher that of many developing countries [40]. Bangladesh farmers presently use N, P, and potassium (K) fertilizers massively [39].

Many previous researchers have studied these problems, but fertilizer application methods have not yet been well investigated. In this study, we examine whether fertilizer broadcasting has an impact on the excessive use of fertilizers.

\subsection{Fertilization Methods and Excessive Use of Fertilizer}

In this section, we review previous studies to trace research gaps and the rationale of this study. A theoretical perspective is discussed at the end of the section to show the background of the work.

Research on fertilizer and plant nutrient has increased enormously in recent decades. For example, between January 1945 and January 2017, 58,650 research works were published on fertilizer and plant nutrients [3]. But very few works have been published on whether fertilizer broadcasting is responsible for excessive use of fertilizers. For example, farmers in Bangladesh primarily depend on chemical fertilizers for higher production practicing the conventional agriculture [41]. Conventional agriculture includes fertilizer broadcasting. There is no alternative to broadcasting for Bangladesh farmers. The unscientific use of fertilizers causes environmental risks in several Asia-pacific countries which annually produce more than 10 tons/ha of high-yielding rice but removes about $350 \mathrm{~kg}$ of soil nutrients per ha [42]. Excessive use of fertilizers causes soil acidification, harmful algae in the water, and high $\mathrm{N}_{2} \mathrm{O}$ emissions, and exhausts the minimum organic ratio of soil [27], as modern fertilizer management technologies (for example, PAT, technology acceptance model (TAM), LCC, SPAD, etc.) are almost never adopted. Fertilizer banding on one side of the seedlings with $60 \mathrm{~kg}$ of nitrogen/ha applied $10 \mathrm{~cm}$ from the seedling at $5 \mathrm{~cm}$ soil depth was selected as the most suitable treatment [19].

One study has shown more grain yield with less fertilizer use by applying site-specific nutrient management (SSNM) based on fertilizer application, in comparison to blanket $\mathrm{N}$ application and other nutrient approaches [38]. Chlorophyll meters and leaf color charts (LCC) are the most appropriate fertilizer management strategy to further improve $\mathrm{N}$ use efficiency [43]. These strategies can diagnose the status of $\mathrm{N}$ in corn leaves. Another way to improve $\mathrm{N}$ efficiency is by using controlled-release urea (CRU). $\mathrm{CRU}$ generally reduces granular urea losses and increases $\mathrm{N}$ concentration [44]. These are, in fact, approaches to manage fertilizer dose efficiency. Furthermore, the nitrogen fertilization model can be used as guidance for quantifying $\mathrm{N}$ fertilization strategy in cereal crop production [45]. This model works as guidance for high yield, not for fertilizer efficiency. Variable rate fertilization (VRF) is a precision agriculture technology that enables smaller trees including resets to be fertilized at lower, most appropriate rates, thus minimizing any excess application [46]. Precision agriculture and variable rate technology keep water and nutrients in the root zone of horticultural crops, thus facilitating maximum uptake efficiency [46].

Site-specific nutrient management (SSNM) is a placement method which can work effectively. In comparison to traditional broadcasting, fertilization in rows (placement) increases the agricultural and physiological effects of the nitrogen [47]. Bangladesh is a country where different types of placement methods can be adopted, which might replace broadcasting method, resulting in fertilizer efficiency.

Our review of existing studies shows that fertilizer broadcasting has not yet been studied directly and comprehensively in the context of excessive use of fertilizers. Previous studies have focused mainly on fertilizer management strategy, fertilizer application comparisons, and fertilization strategies for high yield. The present study examines whether fertilizer broadcasting has an effect on the excessive use of fertilizer or not, and what the scale of any effect is.

\subsection{How Does Traditional Fertilizer Broadcasting Affect the Excessive Use of Fertilizers?}

Theoretically, fertilizer broadcasting (FB) is less effective than other methods [19]. Banding placement method produces the highest net value of corn using the lowest amount of fertilizer $(60 \mathrm{~kg} / \mathrm{ha})$, while fertilizer broadcasting consumes $90 \mathrm{~kg}$ nitrogen/ha [19]. One of the ways to improve $\mathrm{N}$ efficiency is by using controlled-release urea (CRU) [44]. Bangladeshi researchers have developed about 900 agricultural 
technologies, but only one has been developed for fertilizer application efficiency: urea super granules (USG) [48]. Most of the other technologies have been developed for high yield, but their adoption rate is still very low [48].

Several recently developed innovations include diagnostic tools for nutrient status; fertigation; nanotechnologies; nutrient management technologies; and precision farming. Well-established models explaining innovation adoption, such as Rogers' theory of innovation diffusion or Davis' technology acceptance model (TAM), seem suitable to our purpose $[3,49,50]$. Therefore, as a basic model for innovation adoption, Davis's seminal technology acceptance model (TAM) (1989) was selected to guide this literature review $[3,49,51]$.

Finding no suitable alternative approach or model, Bangladeshi farmers customarily use fertilizer broadcasting, as it is a convenient and less time-consuming practice. A good number of fertilizer technologies have been discussed, which can be categorized into three groups: the nutrient diagnosing approach; fertilizer for high yielding and efficient fertilizer application methods. Previous theoretical studies have shown that controlled-release urea achieves more efficient fertilization. Placement and banding methods are very popular; in Bangladesh, the placement method might be the best suited.

\section{Methods and Materials}

\subsection{Data Collection}

To collect data on fertilizer application methods, we opted for anonymous, semi-structured, personal interviews with farmers. The method we approached is effective (face-to-face, focus group discussion, and phone interviews) for data collection, as semi-structured interviews [52] give farmers an opportunity to explain, increasing the response rate by finished questionnaires [52]. We conducted the interview with respondents selected by two-stage cluster sampling.

Our questionnaire consisted of 18 questions categorized into four parts: (i) farmers' personal data (for example, sex, age, education, income, family members, and family bearing capability); (ii) farmers' knowledge level about environmental sustainability (for example, their understanding of environmental sustainability, fertilization methods, training, and amount of fertilizer application); (iii) farmers' capital (land ownership, land rental status, amount of fertilization in rental lands, availability of fertilizers); and (iv) fertilizer governance (for example, the role of agricultural extension agents and availability of soil testing). A copy of the interview questions appears at the end of this study in the supplementary materials.

The questionnaire was prepared in non-scientific language [48] for clarity for the farmers. The set of questions was developed upon consultation with a number of researchers and experts to can maintain scientific ethics and be easier for the farmers to complete. A pilot study was conducted with eight farmers before the full study to prove its quality.

\subsubsection{Sampling and Study Sites}

Bangladesh is located in South Asia at $23.8^{\circ} \mathrm{N}$ and $90.3^{\circ} \mathrm{E}$. In Bangladesh, agriculture is one of the most important sectors and is characterized by a large number of small farmers. The agricultural sector contributes $21 \%$ to gross domestic product (GDP) and employs about $50 \%$ of the labor force [22]. Rice is the staple food for a population of about 160 million and provides over $70 \%$ of direct calorie intake in the country [20]. Four out of 64 districts in Bangladesh were selected for data collection by two-stage cluster sampling. Cluster sampling assumes that selection of a household within a cluster is not independent of the selection of other households; members of a cluster are therefore likely to be similar [53]. A household was defined as a family with one head of household eating and sleeping under the same roof [53]. Two-stage cluster sampling aims to minimize survey costs and control the uncertainty related to estimates of interest [54]; a simple case of multistage sampling, it selects cluster samples in the first stage and then selects a sample of elements from every sampled cluster [55].

The four districts include Manikganj, Noakhli, Dinajpur, and Moulvibazar (Figure 1). The villages Dhakaijora, in Manikganj, and Sondolpur, in Noakhali, were randomly picked for data acquisition. Shibganj 
was selected from Dinajpur and Baraoura from Moulvibazar. We interviewed 61 farm households in Dhakaijora, 54 in Sondolpur, 46 in Dinajpur, and 50 in Moulvibazar following simple random sampling for a total of 211 farm households. The districts chosen are agriculturally important and diversified in terms of agricultural patterns, farmers' agricultural practices, topographical difference, and nature of fertilization; however, the demographic features of all clusters are homogeneous. For the diversification of these agricultural areas, the credibility and reliability of the data can be considered high, as there is an established relationship between researchers and farmers [52].
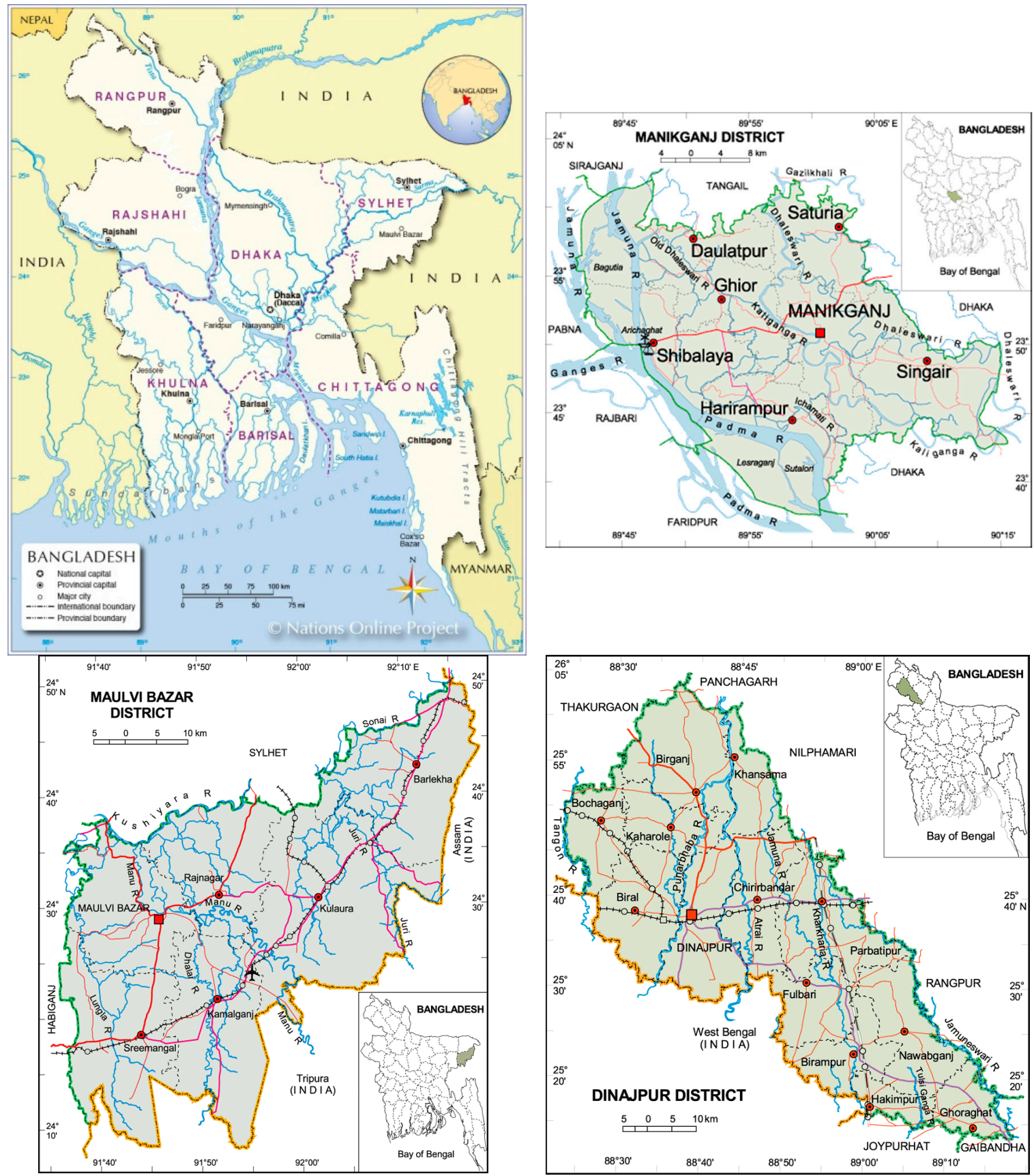

Figure 1. Cont. 


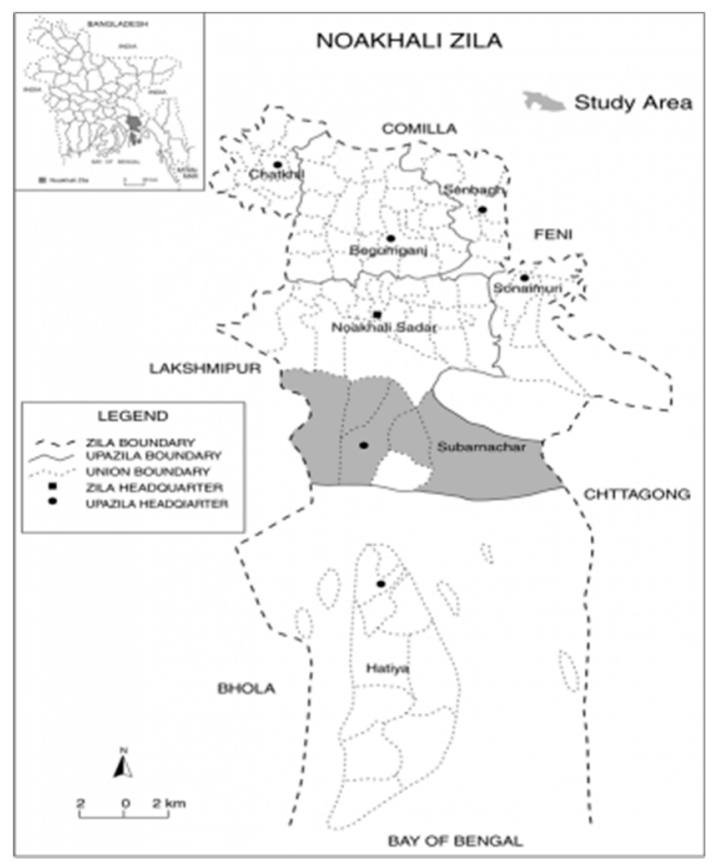

Figure 1. The areas of study: Bangladesh and its agricultural districts Manikganj (common agriculture), Moulvibazar (hilly), Dinajpur (paddies), Noakhali (salinity-prone paddies).

Manikganj lies in the central part of Bangladesh (Dhaka Division). The site is located at $23.85^{\circ} \mathrm{N}$ and $90.01^{\circ} \mathrm{E}$. It has an area of $1383.66 \mathrm{~km}^{2}\left(534.23 \mathrm{mi}^{2}\right)$. Its highest and lowest temperatures are $36{ }^{\circ} \mathrm{C}$ and $12.7^{\circ} \mathrm{C}$ respectively, and it has $2376 \mathrm{~mm}$ of rainfall annually. It has a population of $1,274,829$ (2011 census) at a population density of 2582. The selected village, Dhakaijora, is positioned in the western part of Manikganj. It is an area of all types of agricultural activities.

Moulvibazar is located in the northeastern part of Bangladesh (Sylhet Division). Its area is $2707 \mathrm{~km}$ textsuperscript2 and it has a population of 1.38 million (2011 census). Moulvibazar is located at $24.35^{\circ} \mathrm{N}$ and $91.20^{\circ} \mathrm{E}$. Baraoura is in the Srimangal area of Moulvibazar, where rice, vegetables, and tea plants are primarily grown.

Dinajpur is situated in the northeastern part of Bangladesh at $25.63^{\circ} \mathrm{N}$ and $88.65^{\circ} \mathrm{E}$ and has an area of $3444.30 \mathrm{~km}^{2}$ and a population of 2,990,128 (2011 census). Dinajpur's tropical climate is hot, wet, and humid with an average temperature of $25^{\circ} \mathrm{C}$. Shibganj lies in Dinajpur's industrial and historical zone. Noakhali is located in the southeastern part of Bangladesh at $22.90^{\circ} \mathrm{N}$ and $91.10^{\circ} \mathrm{E}$. The district has an area of 4202 square kilometers and a total population of 3,318,083 (2015 census). The inhabitants experience a tropical climate with a short dry season; Noakhali has significant rainfall all year and an average temperature of $25.6{ }^{\circ} \mathrm{C}$. Salinity-prone Sondolpur village is located along the coastal area of Noakhali, where farmers predominantly grow rice and vegetables.

\subsubsection{Data Process and Analysis}

Data, collected from interviews was input directly into SPSS for Windows (Version 16.0., SPSS Inc., Chicago, IL, USA,) for statistical analysis. Descriptive statistics have been divided into line graphs, for showing comparative fertilizer consumption between the world average and Bangladesh, and tabular statistics showing the basic socioeconomic and demographic features of farmers. Percentile, standard deviation, and variance options were employed in our description. To estimate the correlation and effect of the variables, we applied binary logistic regression.

Logistic regression is commonly used in such fields as clinical studies [56], agriculture, biology, and environmental studies [57]. Logistic regression analysis is a preferred regression method that can be implemented in modeling binary dependent variables [58]. It is an approach used to define 
the relationship between independent variables and binary dependent variables, which are coded as 0 or 1 for two possible categories. The independent variables may be continuous, discrete, binary or a combination of them [58].

We employed a binary dependent variable for the excessive use of fertilizers, coded 1 for "yes" and 0 for "no". Ten independent variables were used in the study, and they are of binary and categorical data. Traditional fertilizer broadcasting was used as a causal independent variable and others are covariates. In our regression model, we applied variance, significance level, and odds ratio options to significantly test the association between targeted dependent and independent variables.

\section{Results}

\subsection{Descriptive Statistics}

Figure 2 shows comparative information of fertilizer consumption between the world average and Bangladesh, time spanning from 2000 to 2015. Bangladesh consumes fertilizers at amounts higher than the global average. It consumed 188 tons in 2002, increasing to 275 in 2012, while global average usage was 103 and 135 tons, respectively. (China (565.26 kg/ha, 2014) and India (138.041 kg/ha, 2014) [59] also consume more chemical fertilizers than the global average. In global terms, China has contributed about $33 \%$ of $\mathrm{N}$ and $36 \%$ of $\mathrm{P}$ in nutrient surpluses [60]).

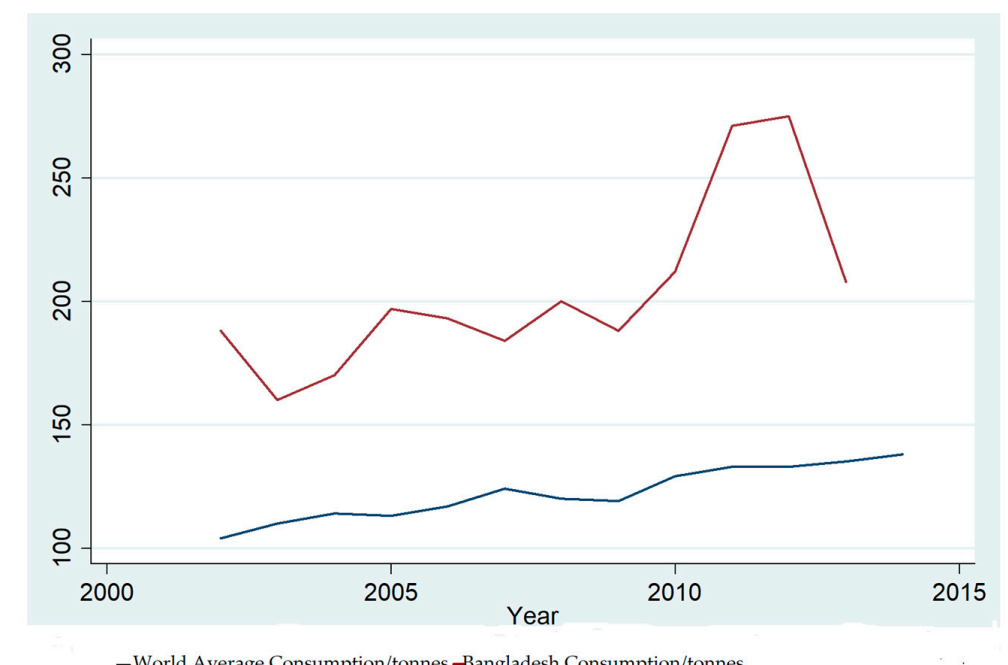

Figure 2. Fertilizer consumption: world average and Bangladesh, 2000-2015.

Table 1 presents the basic and common socioeconomic and demographic features of Bangladesh farmers. It is worth noting that $63.6 \%$ of the respondents were more than 31 years old, $84.8 \%$ earned less than BDT (the currency of the People's Republic of Bangladesh) 6000.00 monthly, and 47.4\% were informally educated. Of the respondents, $61.0 \%$ had no lands of their own and $60 \%$ were using excessive amounts of chemical fertilizers; $42.4 \%$ farmed on rented lands and $62.9 \%$ followed the traditional fertilizer broadcasting method. Respectively, $65.7 \%$ and $74.3 \%$ of the interviewed farmers were formally untrained and unaware of the agricultural environment.

Table 1. Descriptive statistics $(n=211)$.

\begin{tabular}{ccccc}
\hline Variables & Attributes & Percentage & SD & V \\
\hline \multirow{2}{*}{ Age } & $<30$ years & 36.4 & 0.49 & 0.24 \\
& $>31$ years & 63.6 & & \\
\hline \multirow{2}{*}{ Income } & $<$ BDT 6000.00 & 84.8 & 0.73 & 0.54 \\
& $>$ BDT 6000.00 & 15.2 & & \\
\hline
\end{tabular}


Table 1. Cont.

\begin{tabular}{ccccc}
\hline Variables & Attributes & Percentage & SD & V \\
\hline \multirow{2}{*}{ Education } & Informally Educated & 47.4 & 0.5 & 0.25 \\
& Literate (up to12th grade) & 52.6 & & \\
\hline \multirow{2}{*}{ Amount of Fertilization } & Excessive Use (YES) & 63.3 & 0.48 & 0.24 \\
& Small Amount (NO) & 36.7 & & \\
\hline \multirow{2}{*}{ Agro training Adoption } & YES & 34.3 & 0.48 & 0.23 \\
& NO & 65.7 & & \\
\hline \multirow{2}{*}{ Fertilizer Broadcasting } & YES & 62.9 & 0.72 & 0.60 \\
& NO & 19.5 & & \\
\hline \multirow{2}{*}{ Land Ownership } & Landless (YES) & 61.0 & 0.49 & 0.24 \\
& Non-rental landowners (NO) & 39.0 & & \\
\hline \multirow{2}{*}{ Environmental Consciousness } & YES & 25.7 & 0.44 & 0.19 \\
& NO & 74.3 & & \\
\hline \multirow{2}{*}{ Rental Land Farming } & YES & 32.4 & 0.47 & 0.22 \\
& NO & 67.6 & & \\
\hline \multirow{2}{*}{ Cooperation of Ext. Agency } & YES & 66.2 & 0.67 & 0.45 \\
& NO & 63.8 & & \\
\hline
\end{tabular}

The basic socioeconomic and demographic information of responding farmers.

Table 2 shows that the model is statistically significant at $5 \%$, as $\chi^{2}(10, n=211)=16.88, p<0.05$. In addition, the second part of the table reveals that between $5 \%$ and $10 \%$ of the variance in the dependent variable is explained by the model.

Table 2. Omnibus tests of regression model coefficients.

\begin{tabular}{lrccc}
\hline & Chi-Square & df & Significance \\
\hline Step 1 & Step & 16.875 & 10 & 0.047 \\
& Block & 16.875 & 10 & 0.047 \\
& Model & 16.875 & 10 & 0.047 \\
& & -2 Log Likelihood & Cox \& Snell R Square & Nagelkerte R Square \\
& & 261.13 & 0.047 & 0.103
\end{tabular}

Estimation terminated at iteration number 4 because parameter estimates changed by less than 0.001 .

The model's prediction was corrected to $66 \%$ (Table 3). It can be seen that 115 of the cases are observed to be 1 and were correctly predicted to be $1 ; 54$ cases were observed to be 0 and correctly predicted to be 0 . Overall $66 \%$ of cases were correctly predicted. That means the values of the dependent variable are correctly predicted.

Table 3. Classification.

\begin{tabular}{ccccc}
\hline \multicolumn{4}{c}{ Predicted } & \\
\hline Observed & \multicolumn{3}{c}{ Excessive Use of Fert. } \\
\cline { 2 - 4 } & $\begin{array}{c}\text { Excessive Use of } \\
\text { Fertilizers (1) }\end{array}$ & $\begin{array}{c}\text { Small or Rational } \\
\text { Amounts (0) }\end{array}$ & $\begin{array}{c}\text { Percentage } \\
\text { Corrected }\end{array}$ \\
\hline Step 1 Excessive Use of Fertilizer Excessive Use of Fert. & 115 & 18 & 86.5 \\
Small or Rational Use & 54 & 24 & 30.8 \\
Overall Percentage & & & 65.9 \\
\hline
\end{tabular}

The cut value is 0.500 .

Table 4 shows that the association between traditional fertilizer broadcasting method and excessive use of fertilizers is statistically significant, as its coefficient value is 0.891 and $p$-value is 0.004 . Moreover, age and education have statistically significant correlation with the dependent variable (excessive use of fertilizers) ( $\mathrm{B}=0.588,0.563$ and $p=0.084,0.071$, respectively). Income has no statistically significant 
effect on the excessive use of fertilizers. The other independent variables are also not statistically significant in association with the dependent variable. The probability values of these variables are greater than $5 \%$ or $10 \%$ and their coefficient values are also very small.

Table 4. Variables in the Equation.

\begin{tabular}{clccc}
\hline Step1 & \multicolumn{1}{c}{$\boldsymbol{\beta}$} & Standard Error & Wald & Significance \\
\hline Male & 0.237 & 0.391 & 0.368 & 0.544 \\
Farmers Younger than 30 & 0.588 & 0.376 & 2.451 & $0.084^{*}$ \\
Informally Educated & 0.563 & 0.312 & 3.25 & $0.071^{*}$ \\
Farmers of Low Income & 0.144 & 0.329 & 0.192 & 0.661 \\
Untrained & -0.297 & 0.328 & 0.819 & 0.365 \\
Traditional Broadcasting Method & 0.891 & 0.309 & 8.333 & 0.004 *** \\
Landlessness & 0.194 & 0.317 & 0.375 & 0.540 \\
Environmentally Unconscious & 0.000 & 0.343 & 0.000 & 1.000 \\
Rental Land Farming & 0.168 & 0.345 & 0.237 & 0.627 \\
Non-cooperative Extension Agency & -0.132 & 0.336 & 0.154 & 0.695 \\
Constant & -2.252 & 1.261 & 3.188 & 0.074 \\
\hline
\end{tabular}

a. variable(s) entered on step $1 ; \mathrm{b} .{ }^{* * *}$ and ${ }^{*}$ denotes significance at $1 \%$ and $10 \%$ level, respectively.

Traditional fertilizer broadcasting is 2.438 times more likely to have an effect on the excessive use of fertilizers than non-traditional methods (Table 5). In addition, farmers, of low-income, informally educated, and less than 30 years, are responsible for the excessive use of fertilizers more likely to the farmers of formally educated, higher-income, and above 31 years. Untrained farmers and non-cooperative extension agency are associated with excessive fertilization less likely to the trained-up farmers and co-operative agency (Table 5). The table shows that landless, environmentally unconscious, and land renting farmers are more likely to have an impact on the excessive use of fertilizers than land-owning and environmentally conscious farmers.

Table 5. Odds ratio estimation.

\begin{tabular}{ccccc}
\hline Variables & $\beta$ & Exponential ( $\beta)$ & \multicolumn{2}{c}{$\mathbf{9 5 . 0 \%}$ C.I for Exponential( $\beta$ ) } \\
\cline { 2 - 5 } & & & Lower & Upper \\
\hline Male (0) & 0.237 & 1.268 & 0.589 & 2.73 \\
Farmers under 30 (1) & 0.588 & 1.891 & 0.662 & 3.763 \\
Informally Educated (0) & 0.563 & 1.756 & 0.952 & 3.237 \\
Low Income (0) & 0.144 & 1.155 & 0.607 & 2.199 \\
Untrained (1) & -0.297 & 0.743 & 0.391 & 1.414 \\
Traditional Broadcasting Method (0) & 0.891 & 2.438 & 1.331 & 4.465 \\
Landless (0) & 0.194 & 1.214 & 0.652 & 2.262 \\
Environmentally Unconscious (1) & 0.000 & 1.000 & 0.510 & 1.96 \\
Rental Land Farming (0) & 0.168 & 1.183 & 0.601 & 2.326 \\
Non-cooperative Extension Agency (1) & -0.132 & 0.877 & 0.454 & 1.693 \\
Constant & -2.252 & 0.105 & & \\
\hline
\end{tabular}

\subsection{Discussion and Conclusions}

The results show that three variables are statistically significant. We found that traditional fertilizer broadcasting has a statistically significant effect on the excessive use of fertilizers. Age and education have also a positive effect on the excessive use of fertilizers and that is statistically significant. Previous literature found that a higher education level significantly reduces the probability of over-fertilization. Younger, better-educated, and food-secure farmers and net sellers of food grains apply large quantities of organic manure $[61,62]$. The reduction in fertilizer use intensity is larger for the farmers who are male and middle-aged, have acquired a middle level of education, receive a lower share of off-farm 
income [63]. Prior studies show that younger farmers apply the large amounts of organic manure and middle-aged male farmers contribute the reduction in inorganic fertilizer use intensity. Whilst our study found the different result that younger farmers are responsible for the excessive use of fertilizers. The effect of education is consistent with the previous literature. Traditional broadcasting method and younger farmers (less than 30 years) have a significant effect on the excessive use of inorganic fertilizers and these are the key findings of the study. Other independent and control variables are not found statistically significant in regard to the association with the excessive use of fertilizers.

$32.4 \%$ of the respondents (Table 1) in Bangladesh are running their farming activities in rented-in lands and $61.0 \%$ have no their own lands. Landlords rent out their lands to the marginal or landless farmers at a high price, and for a one-year term. These farmers have limited options and prioritize excessive fertilizer use (mainly nitrogen) in pursuit of bumper harvests. Farmers lag behind new fertilization technology, and nitrogen fertilizer is widely accessible, so it can be applied easily by broadcasting, which consumes less time and labor. $74.3 \%$ of the respondents (Table 1) are environmentally unconscious that leads them to adopt the fertilizer broadcasting method. It is important to note that $48 \%$ of Bangladesh's total labor force depends on agriculture $[23,64]$, and large portions of the total population live below the poverty line; most small-scale farmers own no more than 1.0 ha of farmland [23,65]. They have limited access to efficient technologies, fertilizer spreaders or applicators, and little formal training from government extension authorities. As a result, traditional fertilizer broadcasting is popular with farmers, as it requires no formal training or intensive labor.

General farmers hardly use fertilizer based on the recommendation from authorities such as Soil Resource Development Institute (SRDI) and Dept. of Agriculture Extension (DAE). This might be due to lack of awareness, narrow access of farmers to soil testing facility and inadequate motivation by extension people [23]. Row application is superior to broadcasting in terms of efficiency and environmental sustainability, and fertilizer broadcasting uses around $33.3 \%$ more fertilizer than row application [66]. Poor root distribution and inefficient fertilizer application by broadcasting $\mathrm{N}$ fertilizers on potatoes result in restricted $\mathrm{N}$ efficiency [67]. Significant reductions in grain yield have been found in soils with low fertility when the fertilizer was applied to the soil surface $[68,69]$. Bangladesh farmers are habituated in increasing fertilizer rates with broadcasting to gain high yields, beyond concern for environmental harms.

In such conditions, fertilizer application methods and technologies might be transformed to meet up the emerging demands. But there are also many vulnerable farmers in Bangladesh, due to a lack of proper education, financial obstacles, technological disadvantages, and little cooperation with extension agencies. Precision farming (PF) increases profitability, optimizes yield and quality, and reduces cost and environmental impact [13,70-73]. Education, technical skills, familiarity with computers, and the age of farmers were found to be decisive factors in PF adoption [74]. In the study, $47.4 \%$ of respondent farmers are not formally educated, $36.4 \%$ are less than 30 years old (table 1 ), and $84.8 \%$ of them are of low income (less than BDT 6000). The farmers, thus, hardly adopt the advanced technology of fertilization and practice broadcasting method for higher turnover. Spinner spreaders and granular urea application machines could hardly be used at field level. Leaf color chart (LCC) technology and chlorophyll meters have not yet been used to diagnose the nutrient scale of plant leaves for sustainable fertilizer management.

There is a significant association between mass inorganic fertilization and technological non-advancement, a lack of scientific knowledge, a shortage of proper information, and smallholder farm size [75]. Gains in crop yield and higher earnings are positively correlated with intensive fertilizer use [62]. The socio-economic conditions of Bangladesh (Table 1) lead to broadcasting significant amounts of fertilizer. Researchers have developed urea super granules (USG) technology suited to Bangladeshi agriculture, but its adoption rate is very low as it is a labor intensive and time-consuming technology [76]. Farmers cannot apply it, in consideration of their low turnover.

The present study has a few limitations. The sample size of the study is small compared to the population of Bangladesh. In addition, the interviews were conducted in unscientific local language so 
that the farmers could understand the questionnaire accurately. We recommend further research on the following questions:

(1) How to adopt an integrated placement method in Bangladesh?

Different types of placement methods might be considered to reduce the excessive use of fertilizers. With consideration of soil, crop, and time, an integrated placement method should be applied.

(2) How to develop and adopt earthworm organic manure at an optimum level?

Earthworm organic manure can be adopted so that the pressure of inorganic fertilizer might be reduced. This can be applied mixing with inorganic fertilizers.

We find that traditional fertilizer broadcasting has a significant effect on the excessive use of inorganic fertilizers and younger farmers are also significantly associated with excessive fertilization. Fertilizer broadcasting creates obstacles to both agricultural and environmental sustainability in Bangladesh. Fertilizer placement might be one solution for sustainable fertilizer management given the context of Bangladesh farmers' socioeconomic and demographic status. Efficient fertilizer placement is attracting increasing interest as tillage systems change, economic profitability becomes tighter and environmental awareness increases [77]. When soil test facilities are low, soil moisture and/or precipitation is limited, or land is rented, and when fertilizer efficiency and economic return are to be maximized [77], localized placement methods are strongly recommended for small grains and corn.

Deep, drill, row and side dressing placement methods could be recommended based on soil quality, crop type, weather condition, and farmers' social background. For example, seed and fertilizer together can be deposited while sowing. These methods are significantly viable for cereal crops, cotton, and grasses. In row placement, fertilizers are placed in a continuous band on one or both sides of the seedlings or seeds, when seeds and plants are sown together. This process is very useful for sugarcane, potato, maize, tobacco, cereals, and vegetable crops. In growing crops, fertilizers are usually spread by hand between and around rows. Maize, sugarcane, tobacco, and cereal crops are best suited to this method.

Between paddy rows, fertilizers can be deposited $2.5-5.0 \mathrm{~cm}$ deep using the deep placement method. In tightly spaced crops such as pulses and legumes, broadcasting is an efficient process. Placement is less effective for crops that provide small yield. Policymakers can formulate fertilizer policy emphasizing the implementation of placement methods so that fertilizer management and environmental services can be efficient.

Supplementary Materials: The following are available online at http:/ /www.mdpi.com/2071-1050/10/3/759/s1, Part-I: Personal data, Part 2: Farmers' Knowledge about Environmental Sustainability, Part 3: Farming Capitals, Part 4: Fertilizer governance.

Acknowledgments: We are grateful to our respected editors and reviewers for their valued comments and suggestions that helped us to prepare the paper.

Author Contributions: Dunfu Zhang designed and analyzed the data of the research work, and K. M. Atikur Rahman collected data and wrote the paper.

Conflicts of Interest: The authors declare no conflict of interest.

\section{References}

1. Godfray, H.C.J.; Beddington, J.R.; Crute, I.R.; Haddad, L.; Lawrence, D.; Muir, J.F.; Pretty, J.; Robinson, S.; Thomas, S.M.; Toulmin, C. Food security: The challenge of feeding 9 billion people. Science 2010, 327, 812-818. [CrossRef] [PubMed]

2. FAO (Food and Agriculture Organization of the United Nations). FAOSTAT Database: Agriculture Production; Food and Agriculture Organization of the United Nations: Rome, Italy, 2015.

3. Hasler, K.; Olfs, H.-W.; Omta, O.; Bröring, S. Drivers for the Adoption of Different Eco-Innovation Types in the Fertilizer Sector: A Review. Sustainability 2017, 9, 2216. [CrossRef] 
4. United Nations. Key Findings and Advance Tables. In World Population Prospects: The 2015 Revision, ESA/P/WP.241; United Nations: New York, NY, USA, 2015.

5. Hazell, P.; Wood, S. Drivers of change in global agriculture. Philos. Trans. R. Soc. B Biol. Sci. 2008, 363, 495-515. [CrossRef] [PubMed]

6. Pretty, J.; Hine, R. Reducing Food Poverty with Sustainable Agriculture: A Summary of New Evidence; University of Essex: Essex, UK, 2011.

7. Tilman, D.; Cassman, K.G.; Matson, P.A.; Naylor, R.; Polasky, S. Agricultural sustainability and intensive production practices. Nature 2002, 418, 671-677. [CrossRef] [PubMed]

8. Tilman, D. The ecological consequences in changes in biodiversity: A search for general principles. Ecology 1999, 80, 1455-1474. [CrossRef]

9. Tilman, D.; Reich, P.B.; Knops, J.; Wedin, D.; Mielke, T.; Lehman, C. Diversity and productivity in a long-term grassland experiment. Science 2001, 294, 843-845. [CrossRef] [PubMed]

10. Jiao, X.Q.; Lyu, Y.; Wu, X.B.; Li, H.G.; Cheng, L.Y.; Zhang, C.C.; Yuan, L.X.; Jiang, R.F.; Jiang, B.W.; Rengel, Z.; et al. Grain production versus resource and environmental costs: Towards increasing sustainability of nutrient use in China. J. Exp. Bot. 2016, 67, 4935-4949. [CrossRef] [PubMed]

11. Tucker, C.J. Red and photographic infrared linear combinations for monitoring vegetation. Remote Sens. Environ. 1979, 8, 127-150. [CrossRef]

12. Sharma, L.K.; Bu, H.; Denton, A.; Franzen, D.W. Active-Optical Sensors Using Red NDVI Compared to Red Edge NDVI for Prediction of Corn Grain Yield in North Dakota, U.S.A. Sensors 2015, 15, 27832-27853. [CrossRef] [PubMed]

13. Paustian, M.; Theuvsen, L. Adoption of Precision Agriculture technologies by German crop Farmers. Precis. Agric. 2017, 18, 701. [CrossRef]

14. Yan, D.; Zhu, Y.; Wang, S.; Cao, W. A quantitative knowledge-based model for designing suitable growth dynamics in rice. Plant Prod. Sci. 2006, 9, 93-105. [CrossRef]

15. Zhu, Y.; Cao, W.; Dai, T.; Tian, Y.; Yao, X. A knowledge model system for wheat production management. Pedosphere 2007, 17, 172-181. [CrossRef]

16. Dobermann, A.; Cassman, K.G. Plant nutrient management for enhance productivity in intensive grain production systems of the United States and Asia. Plant Soil 2002, 247, 153-175. [CrossRef]

17. Swietlik, D. Causes and Consequences of Overfertilization in Orchards. HortTechnology 1992, 2, 112-132.

18. International Fertililizer Development Centre (IFDC). Fertilizer Deep Placement (FDP); IFDC: Muscle Shoals, AL, USA, 2013; Available online: https:/ /ifdc.org/fertilizer-deep-placement/ (accessed on 14 August 2017).

19. Bakhtiari, M.R.; Ghahraei, O.; Ahmad, D.; Yazdanpanah, A.R.; Jafari, A.M. Selection of fertilization method and fertilizer application rate on corn yield. Agric. Eng. Int. CIGR J. 2014, 16, 10-14.

20. Alam, M.J.; Van Huylenbroeck, G.; Buysse, J.; Begum, I.A.; Rahman, S. Technical efficiency changes at the farm-level: A panel data analysis of rice farms in Bangladesh. Afr. J. Bus. Manag. 2011, 5, 5559-5566.

21. Anam, T. Bangladesh's Rotten-Mango Crisis. The New York Times, Sec.: The Opinion Pages. Web. Available online: http:/ / www.nytimes.com/2014/07/03/opinion/tahmima-anam-bangladeshs-rotten-mango-crisis.html (accessed on 16 June 2017).

22. Bangladesh Bureau of Statistics (BBS). Preliminary Report on the Agricultural Census of Bangladesh 2009; Bangladesh Bureau of Statistics (BBS): Dhaka, Bangladesh; Available online: http://www.bbs.gov.bd/ dataindex/Pre-report-Agri-census-2008-Final.pdf (accessed on 11 May 2017).

23. Sultana, J.; Siddique, M.N.A.; Abdullah, M.R. Fertilizer recommendation for Agriculture: Practice, practicalities and adaptation in Bangladesh and Netherlands. Int. J. Bus. Manag. Soc. Res. 2014, 1, 21-40. [CrossRef]

24. Fertilizer Research Institute (FRI). Fertilizer Recommendation Guide; Bangladesh Agricultural Research Council (BARC): Dhaka, Bangladesh, 2012; p. 275.

25. Hasanuzzaman, M.; Nahar, K.; Alam, M.M.; Hossain, M.Z.; Islam, M.R. Response of transplanted rice to different application methods of urea fertilizer. Am.-Eur. J. Sustain. Agric. 2009, 5, 01-05.

26. BRRI (Bangladesh Rice Research Institute). Nitrogen Fertilizer on Morpho-Physiological Adhunik Dhaner Chash (In Bengali), 14th ed.; Bangladesh Rice Research Institure: Gazipur, Bnagladesh, 2008; p. 39.

27. Manono, B.O. Carbon dioxide, nitrous oxide and methane emissions from the Waimate District (New Zealand) pasture soils as influenced by irrigation, effluent dispersal and earthworms. Cogent Environ. Sci. 2016, 2, 1256564. [CrossRef]

28. Kasraei, R. Plant Nutrition Science Abstract, 2nd ed.; Tabriz University Press: Tibriz, Iran, 1993. (In Farsi) 
29. Malakoti, M.J. Sustainable Agriculture and Yield Increase through Optimization of Fertilizer Usage in Iran, 2nd ed.; Agricultural Education: Tibriz, Iran, 1999. (In Farsi)

30. Chen, J.; Tang, C.; Sakura, Y.; Yu, J.; Fukushima, J. Nitrate Pollution from Agriculture in Different Hydrogeological Zones of the Regional Groundwater Flow System in the North China Plain. Hydrogeol. J. 2005, 13, 481-492. [CrossRef]

31. Galloway, J.N.; Townsend, A.R.; Erisman, J.W.; Bekunda, M.; Cai, Z.; Freney, J.R.; Martinelli, L.A.; Seitzinger, S.P.; Sutton, M.A. Transformation of the Nitrogen Cycle, Recent Trends, Questions, and Potential Solutions. Science 2008, 320, 889-892. [CrossRef] [PubMed]

32. Vitousek, P.M.; Aber, C.D.; Howarth, R.W.; Likens, G.E.; Matson, P.A.; Schindler, D.W.; Schlesinger, W.H. Tilman, D.G. Human Alterations of the Global Nitrogen Cycyle: Sources and Consequences. Ecol. Appl. 1997, 7, 737-750.

33. Serpil, S. Investigation of effect of chemical fertilizers on environment. APCBEE Proc. 2012, 1, $287-292$. [CrossRef]

34. Bangladesh Agricultural Research Council (BARC). Fertilizer Recommendation Guide—2005; Soil Publications: Gazipur, Bangladesh, 2005.

35. Good, A.G.; Beatty, P.H. Fertilizing Nature: A Tragedy of Excess in the Commons. PLoS Biol. 2011, 9, e1001124. [CrossRef] [PubMed]

36. U.S. Environmental Protection Agency. Hypoxia in the Northern Gulf of Mexico: An Update by the EPA Science Advisory Board; EPA-SAB-08-00; U.S. Environmental Protection Agency: Washington, DC, USA, 2007.

37. East Pakistan Bureau of Statistics (EPBS). Statistical Abstract for East Pakistan (1950-51 to 1959-60); Govt. of East Pakistan, Bureau of Statistics: Dhaka, Pakistan, 1964.

38. Quasem, M.A. Fertilizer Use in Bangladesh: 1965-66 to 1975-76; Bangladesh Institute of Development Studies: Dhaka, Bangladesh, 1978.

39. Rahman, K.M.A. Agrochemical use, environmental and health hazards in Bangladesh. Int. Res. J. Interdis. Multidis. Stud. 2015, 1, 757-759. Available online: http:/ /www.irjims.com/files/K_5xhsw1pt.M-AtiqurRahaman.pdf (accessed on 27 December 2017).

40. Bruce, K. The Great Lakes. An Environmental Atlas and Resource Book, 1st ed.; US EPA \& Environment Canada: Chicago, IL, USA, 1988; ISBN-13 978-0662234418.

41. Karim, R.; Aktar, M.A. Fertilizer use pattern on agriculture in Salua area of Chougachha Upazila, Jessore, Bangladesh. J. Biosci. Agric. Res. 2016, 3, 96-103.

42. FAO (Food and Agriculture Organization of the United Nations). Case Studies on Policies and Strategies for Sustainable Soil Fertility and Fertilizer Management in South Asia; Office of Knowledge Exchange, Research and Extension: Bangkok, Thailand, 2011; pp. 1-3. ISBN 978-92-5-106914-1.

43. Singh, B.; Gupta, R.K.; Singh, Y.; Gupta, S.K.; Singh, J.; Bains, J.S.; Vashishta, M. Need-Based Nitrogen Management Using Leaf Color Chart in Wet Direct-Seeded Rice in Northwestern India. J. New Seeds 2006, 8, 35-47. [CrossRef]

44. Kiran, J.K.; Khanif, Y.M.; Amminuddin, H.; Anuar, A.R. Effects of Controlled Release Urea on the Yield and Nitrogen Nutrition of Flooded Rice. Commun. Soil Sci. Plant Anal. 2010, 41, 811-819. [CrossRef]

45. Cao, J.; Jing, Q.; Zhu, Y.; Liu, X.; Zhuang, S.; Chen, Q.; Cao, W. A Knowledge-Based Model for Nitrogen Management in Rice and Wheat. Plant Prod. Sci. 2009, 12, 100-108. [CrossRef]

46. Schumann, A.W. Precise placement and variable rate fertilizer application technologies for horticultural crops. HortTechnology 2010, 20, 34-40.

47. Szulc, P.; Waligóra, H.; Michalski, T.; Rybus-Zając, M.; Olejarski, P. Efficiency of nitrogen fertilization based on the fertilizer application method and type of maize cultivar (Zea mays L.). Plant Soil Environ. 2016, 62, 135-142. [CrossRef]

48. Bangladesh Agricultural Research Council (BARC). Agricultural Technology Transfer Report-2015; BARC Press: Gazipur, Bangladesh, 2016.

49. Davis, F.D. Perceived usefulness, perceived ease of use, and user acceptance of information technology. MIS Q. 1989, 13, 319-340. [CrossRef]

50. Rogers, E.M. Diffusion of Innovations, 5th ed.; Free Press: New York, NY, USA, 2003; p. 576.

51. Davis, F.D.; Bagozzi, R.P.; Warshaw, P.R. User acceptance of computer technology: A comparison of two theoretical models. Manag. Sci. 1989, 35, 982-1003. [CrossRef] 
52. Latawiec, A.E.; Królczyk, J.B.; Kuboń, M.; Szwedziak, K.; Drosik, A.; Polańczyk, E.; Grotkiewicz, K.; Strassburg, B.B.N. Willingness to Adopt Biochar in Agriculture: The Producer's Perspective. Sustainability 2017, 9, 654. [CrossRef]

53. Rose, A.M.C.; Grais, R.F.; Columbier, D.; Ritter, H. A comparison of cluster and systematic sampling methods for measuring crude mortality. Bull. World Health Organ. 2006, 84, 290-296. [CrossRef] [PubMed]

54. Pfeffermann, D.C.; Rao, R. Handbook of Statistics Vol.29 A Sample Surveys: Theory, Methods and Infernece; Elsevier B.V.: Amsterdam, The Netherlands, 2009; ISBN 978-0-444-53124-7.

55. Ahmed, S. Methods in Sample Surveys; The Johns Hopkins University Press: Baltimore, MD, USA, 2009.

56. Gardside, P.S.; Glueck, C.J. The Important Role of Modifiable Dietary and Behaviour Characteristic in the Causation and Prevention of Coronary Heart Disease Hospitalization and Mortality. J. Am. Coll. Nutr. 1955, 14, 717-719.

57. Wang, P.; Putterman, M.L. Mixed logistic regression models. J. Agric. Biol. Environ. Stat. 1998, 3, $175-200$. [CrossRef]

58. Korkmaz, M.; Guney, S.; Yigiter, S.Y. The Importance of Logistic Regression Implementations in the Turkish Livestock Sector and Logistic Regression Implementations/Fields. Harran Tarim Ve Gida Bilimleri Dergisi. 2012, 16, 25-36.

59. The World Bank (WB). World Development Indicators: Agricultural Inputs—2014; Data Bank: Washington, DC, USA, 2015.

60. West, P.C.; Gerber, J.S.; Engstrom, P.M.; Mueller, N.D.; Brauman, K.A.; Carlson, K.M.; Cassidy, E.S.; Johnston, M.; MacDonald, G.K.; Ray, D.K.; et al. Leverage points for improving global food security and the environment. Science 2014, 345, 325-328. [CrossRef] [PubMed]

61. Chianu, J.N.; Tsujii, H. Determinants of farmers' decision to adopt or not adopt inorganic fertilizer in the savannas of northern Nigeria. Nutr. Cycl. Agroecosyst. 2004, 70, 293-301. [CrossRef]

62. Zhou, Y.; Yang, H.; Mosler, H.-J.; Abbaspour, K.C. Factors affecting farmers decisions on fertilizer use: A case study for the Chaobai watershed in Northern China. Consil. J. Sustain. Dev. 2010, 4, 80-102. [CrossRef]

63. Pan, D.; Kong, F.; Zhang, N.; Ying, R. Knowledge training and the change of fertilizer use intensity: Evidence from wheat farmers in China. J. Environ. Manag. 2017, 197, 130-139. [CrossRef] [PubMed]

64. Huq, S.I.; Shoaib, J.M. The Soils of Bangladesh; Springer: Dordrecht, The Netharland, 2013; Volume 1, ISBN 978-94-007-1128-0. [CrossRef]

65. Rahman, M.Z.; Yamao, M.; Alam, M. Barriers faced by small farmers in adopting the integrated plant nutrient system for sustainable farming development. Sabaragamuwa Univ. J. 2007, 7, 3-21. [CrossRef]

66. Hawkins, A. Time, Method of Application, and Placement of Fertilizer for Efficient Production of Potatoes in New England. Am. Potato J. 1954, 31, 106-113. [CrossRef]

67. Hofman, G.; Verstegen, P.; Demyttenaere, P.; Van Meirvenne, M.; Delanote, P.; Ampe, G. Comparison of row and broadcast $\mathrm{N}$ application on $\mathrm{N}$ efficiency and yield of potatoes. In Optimization of Plant Nutrition. Developments in Plant and Soil Sciences; Fragoso, M.A.C., Van Beusichem, M.L., Houwers, A., Eds.; Springer: Dordrecht, The Netherland, 1993; Volume 53. [CrossRef]

68. Lacerda, M.C.; Nascente, A.S.; Carvalho, M.C.S.; Mondo, V.H.V. Broadcast fertilizer rate impacts common bean grain yield in a no-tillage system. Afr. J. Agric. Res. 2015, 10, 1773-1779. [CrossRef]

69. Kurihara, C.H.; Hernani, L.C. Adubação Antecipada da soja em Plantio Direto Requer Observação de Alguns Critérios. Available online: http:/ /www.diadecampo.com.br/zpublisher/materias/Materia.asp?secao= Artigos\%20Especiais\&id=25155 (accessed on 21 July 2013).

70. Fountas, S.; Blackmore, S.; Ess, D.; Hawkins, S.; Blumhoff, G.; Lowenberg-De Boer, J.; Sorenson, C.G. Farmers experience with precision agriculture in Denmark and the US eastern corn belt. Precis. Agric. 2005, 6, 121-141. [CrossRef]

71. Stafford, J.V. Implementing precision agriculture in the 21st century. J. Agric. Eng. Res. 2000, 76, $267-275$. [CrossRef]

72. Reichardt, M.; Jürgens, C.; Klöble, U.; Hüter, J.; Moser, K. Dissemination of precision farming in Germany: Acceptance, adoption, obstacles, knowledge transfer and training activities. Precis. Agric. 2009, 10, 525-545. [CrossRef]

73. Aubert, B.A.; Schroeder, A.; Grimaudo, J. IT as enabler of sustainable farming: An empirical analysis of farmers' adoption decision of precision agriculture technology. Decis. Support Syst. 2012, 54, 510-520. [CrossRef] 
74. McBride, W.D.; Daberkow, S.G. Information and the adoption of precision farming technologies. J. Agribus. 2003, 21, 21-38.

75. Ju, X.; Gu, B.; Wu, Y.; Galloway, J.N. Reducing China's fertilizer use by increasing farm size. Glob. Environ. Chang. 2016, 41, 26-32. [CrossRef]

76. Department of Agricultural Extension (DAE). Technology Transfer Report, 2008; DAE: Dhaka, Bangladesh, 2013.

77. Randall, G.W.; Hoeft, R.G. Placement Methods for Improved Efficiency of P and K Fertilizers: A Review. J. Prod. Agric. 1988, 1, 70-79. [CrossRef] 